BIJDRAGEN TOT DE KENNIS DER FAUNA VAN CURAÇAO.

Resultaten eener Reis van Dr. C. J. VAN DER HORST in 1920.

\title{
BRACHYURAN CRABS COLLECTED AT CURAÇAO
}

\author{
BY \\ MARY J. RATHBUN \\ Associate in Zoology, United States National Museum.
}

(With one plate and four text figures).

In 1920 a report ') on Dr. BoEKE's collection of crabs and shrimps from Curaçao and other Dutch West Indian Islands was published. Dr. VAN DER HORST's collection forms an important addition to the fauna of Curaçao, especially as to the Xanthids and Majids, or spider crabs. Four new species were discovered among the small forms, and have already been briefly described ${ }^{2}$ ). They are more fully described and figured below.

Family Dromider.

Dromia erythropus (George Edwards).

Cancer erythropus George Edwards, in Catesby, Nat. Hist. Carolina, etc., vol. 2, 1771, No 37.

Caracas Bay: under stones near shore, 3. V.20, 2 juv; in coral, 13. V. 20, 1 juv.

\section{Family CÀLAPPIDE.}

Calappa gallus (Herbst).

Cancer gallus Herbst, Naturg. d. Krabben u. Krebse, vol. 3, part 3, 1803, pp. 18 and 46, pl. 58, fig. 1.

Caracas Bay: seine, 8. IV. 20, 1 万'.

Family LEUCOSIIDE.

Randallia curaçaoensis Rathbun. (Plate III, figs. 1, 2, 3).

Proc. Biol. Soc. of Washington, vol. 35, 1922, p. 103.

Spanish Water: 3. IV. 20, 1 ovigerous $q$, holotype; 1 smaller, immature $\$$, paratype.

Length of carapace of holotype $8.4 \mathrm{~mm}$., width $7.5 \mathrm{~mm}$.

Carapace subcircular, covered, except on the anterior and antero-lateral portions, with large, unequal, close-set, pustulous granules; intestinal region well defined, cardiac region ill defined, gastric and hepatic regions not delimited. A granulated tubercle on the hepatic region. The tuberculate anterolateral margin terminates at the swollen and tuberculate pterygostomian protuberance. Intestinal margin arcuate, without lobes or spines in female. Front bilobed, each lobe covering an antennule; median point not visible from above and exceeded by the projecting epistome. Orbit without conspicuous emarginations.

1) Stalk-eyed Crustaceans of the Dutch West Indies, in: Rapport betreffende een voorloopig onderzoek naar den toestand van de Visscherij en de Industrie van Zeeproducten in de Kolonie Curaçao, uitgebracht door Prof. Dr. BoEKE, part 2, 's Gravenhage, 1919 (1920), pp. 317-349, 5 text-figs.

2) New species of crabs from Curaçao. Proceedings of the Biological Society of Washington, vol. 35, Oct. 17, 1922, pp. 103-104. 
Chelipeds covered with flat granulations, coarse on the merus, becoming gradually finer until near the fingers. Ambulatory legs slender, sub-cylindrical, finely granulate.

Abdomen and exposed part of sternum of female coarsely granulate.

Distinguished by its coarse, flat granulation, simple outline and absence of spines.

\section{Family PORTUNide.}

Callinectes marginatus (A. Milne Edwards).

Neptunus marginatus A. Milne Edwards, Arch. Mus. Hist. Nat. Paris, vol. 10, 1861, p. 318, pl. 30.

Spanish Water: 3. IV. 20, 1 immature ㅇ.

Spanish Port: 10. IV. 20, $1 \delta^{\lambda} ; 20$. V. 20, 1 \% juv.

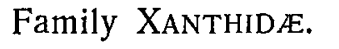

Carpilius corallinus (Herbst).

Cancer corallinus Herbst, Naturg. d. Krabben u. Krebse, vol. 1, 1783, p. 133, pl. 5, fig. 40.

Caracas Bay: in net, 26.IV.20, $10^{7} 19$ and 27. IV. 20, $10^{7}$; 24. IV. 20, $10^{7}$.

Liomera dispar (Stimpson).

Chlorodius dispar Stimpson, Bull. Mus. Comp. Zoöl., vol. 2, 1871, p. 140.

Caracas Bay: in coral, 7.IV. 20, $3 \sigma^{\lambda} 2$ ㅇ, $1 \sigma^{\lambda}$ and 1 ㅇ have both branchial regions swollen by isopod parasites; 1.V.20, $10^{7}$, also parasitized on both sides.

Liomera longimana A. Milne Edwards.

Nouv. Arch. Mus. Hist. Nat. Paris, vol. 1, 1865, p. 221, pl. 12, fig. 7.

Caracas Bay: 19. IV. 20, $10^{7}$.

Platypodia spectabilis (Herbst).

Cancer spectabilis Herbst, Naturg. d. Krabben u. Krebse, vol. 2, 1794, p. 153, pl. 37, fig. 5.

West Punt: 14. V. 20, $3 \sigma^{7} 1$ ㅇ.

Caracas Bay: 5. V. 20, $10^{7}$.

Xanthodius parvulus (Fabricius).

Cancer parvulus Fabricius, Ent. Syst. auct. et emend., vol. 2, 1793, p. 451.

Caracas Bay: under stones near shore, 3. V. 20, 1 q.

Leptodius floridanus (Gibbes).

Chlorodius floridanus Gibbes, Proc. Amer. Assoc. Adv. Sci., vol. 3, 1850, p. 175.

Spanish Port: 10. IV. 20, 1 q.

Cycloxanthops denticulatus (White).

Xantho denticulatus White, Ann. Mag. Nat. Hist., ser. 2, vol. 2, 1848, p. 285.

Caracas Bay: under stones near shore, 3. V. 20, $1 \sigma^{7} 2$ \%

Eurypanopeus abbreviatus (Stimpson).

Panopeus abbreviatus Stimpson, Ann. Lyc. Nat. Hist. N. Y., vol. 7, 1860, p. 211.

Caracas Bay: under stones near shore, 3. V. 20, $39^{-}(2$ ovigerous).

Panopeus herbstii Milne Edwards.

Hist. Nat. Crust., vol. 1, 1834, p. 403.

Caracas Bay: small pool, 26. IV. 20, 1 \% juv., soft shell; under a stone, 26.IV.20, $1 \sigma^{7}$. Spanish Water: 17. IV.20, 3 juv.; 7.V. 20, 1 q.

\section{Panopeus occidentalis Saussure.}

Rev, et Mag. Zool., ser. 2, vol. 9, 1857, p. 502.

Spanish Port: 10. IV.20, 1 immature 
Panopeus rugosus A. Milne Edwards.

Crust. Rég. Mex. 1880, p. 314, pl. 57, fig. 4.

Spanish Water: 3. IV.20, $2 \sigma^{7} 3$ juv.; in sand, 4. V.20, 1 q juv.; from Porites furcata, 1 q juv.

Spanish Port: 6. V. 20,1 $0^{7}$ juv.; in sand, 17. IV. 20, 1 ovigerous Q.

Caracas Bay: 19. IV. 20, $10^{\text {J }}$; in coral, 13. V.20, 1 \% 1 juv.

\section{Panopeus boekei Rathbun.}

Rapport van de Visscherij en de Industrie van Zeeproducten in de Kolonie Curaçao, uitgebracht door Prof. Dr. J. BOEKE, part 2, 1920, p. 336 [20], text-figs. 4 and 5.

Spanish Port: 10.IV. 20, 1 ㅇ․

Caracas Bay: 1. V. 20, 1 \%; 26. IV. 20, $3 \sigma^{7}$; in sand, 13. V. 20, $1 \sigma^{7}$.

Hexapanopeus čaribbaeus (Stimpson).

Micropanope caribbaea Stimpson, Ann. Lyc. Nat. Hist. N. Y., vol. 10, 1871, p. 108.

Caracas Bay: under stones near shore, 3. V.20, 1 ㅇ from coral, 28. IV.20, 1 juv.

Actaea rufopunctata nodosa Stimpson.

Actaea nodosa Stimpson, Ann. Lyc. Nat. Hist. N. Y., vol. 7, 1860, p. 203.

Caracas Bay: in coral, 7. IV. 20, $10^{7}$.

Spanish Port: 20. V.20,1 1 ㅇ.

\section{Actaea palmeri Rathbun.}

Proc. U. S. Nat. Mus., vol. 17, 1894, p. 85.

Caracas Bay: among branches of Porites furcata, 29. IV. 20, $10^{\pi}$.

Actaea setigera (Milne Edwards).

Xantho setiger Milne Edwards, Hist. Nat. Crust., vol. 1, 1834, p. 390.

Caracas Bay: in coral, $10^{7} 4$ juv.; among branches of Porites furcata, 29. IV. 20, 1 juv.; under stones, 18. V. 20, $10^{7} 1$ juv.; under stones near shore, 3. V. 20, $1 \sigma^{7} 1$ ㅇ 4 juv.

Actaea bifrons Rathbun.

Bull. Lab. Nat. Hist. State Univ. Iowa, vol. 4, 1898, p. 262, pl. 4, figs. 3 and 4.

Spanish Water: in Porites furcata, 1 \%.

Length of carapace $10.5 \mathrm{~mm}$. , width $15.2 \mathrm{~mm}$.

Xanthias granulimanus (Stimpson).

Pilumnus granutimanus Stimpson, Bull. Mus. Comp. Zoöl., vol. 2. 1871, p. 143.

Caracas Bay: in coral, 7.IV.20, $20^{7}$; in coral, 7. IV. 20, 1 \% juv.; 5.V.20, 1 ; ; under stones near shore, 3. V. 20,1 ovigerous .

Xanthias vestitus Rathbun. (Plate III, figs. 4, 5, 6).

Proc. Biol. Soc. Washington, vol. 35, 1922, p. 103.

Spanish Port: 6. V. 20, $3 \sigma^{7}$ (1 holotype) 4 c; 16. IV. 20, $2 \sigma^{7} 6$. (1 ovigerous).

Length of carapace of $\sigma^{7}$ holotype, $4.6 \mathrm{~mm}$., width $6.4 \mathrm{~mm}$; l length of female, $5.2 \mathrm{~mm}$., width $7.6 \mathrm{~mm}$.

Entire animal except extremities of fingers covered with a very short feltlike pubescence. which conceals granules and other inequalities and obscures, the antero-lateral teeth. Carapace very flat posteriorly, anterior third deflexed. When the felt is removed the regions are seen to be fairly well indicated, the urogastric region is depressed, the grooves forming an $H$ in the middle of the carapace and especially deep. Fine granules are scatiered sparsely on the antero-lateral, postero-lateral and posterior portions. There are four shallow, blunt, antero-lateral teeth besides the angle of the orbit which is small and inconspicuous; the first is long and low, the second and third are subequal, the fourth smallest. Carapace very nearly as wide at fourth tooth as at third. Fronto-orbital distance a little over half as great as width of carapace; front, between antennae, less than one third the carapace width, separated from orbital margins by deep grooves, anterior margin bilobed, median notch $\mathrm{V}_{-}$-shaped. 
Chelipeds subequal; carpus and manus covered with granules; fingers light-colored; propodal finger horizontal except at tip where it crosses the dactylus, gape narrow. Ambulatory legs smooth.

May at once be told by its feltlike covering and pale fingers.

Phymodius maculatus (Stimpson).

Chlorodius maculatus Stimpson, Ann. Lyc. Nat. Hist. N. Y., vol. 7, 1860, p. 210 [82].

Caracas Bay: in sand, 13. V.20, 1 ㅇ juv.; 1. V. 20, 1 juv., identification uncertain.

Ozius reticulatus (Desbonne and Schramm).

Lagostoma reticulata Desbonne and Schramm, Crust. Guadeloupe, 1867, p. 34, pl. 4, fig.' 6 .

Spanish Bay: among stones in the surf, 11. V.20, $10^{\pi} 1$ ovigerous .

Pilumnus gemmatus Stimpson.

Ann. Lyc. Nat. Hist. N. Y., vol. 7, 1860, p. 214.

Caracas Bay: in coral, 5. V.20, 1 우 and 23.IV.20, 1 q.

Spanish Water: in Siderastrea, 29. IV.20, 1 ; in Porites furcata, 5. V. 20, $10^{7} 191$ juv.

Pilumnus holosericus Rathbun.

Bull. Lab. Nat. Hist. State Univ. Iowa, vol. 4, 1898, p. 268, pl. 5, fig. 1.

Caracas Bay: under stones near shore, 3. V.20, $2 \delta^{\nearrow}$; in coral, 13. V.20, $1 \sigma^{7} 5$ 우 (1 ovigerous).

Pilumnus floridanus Stimpson.

Bull. Mus. Comp. Zoöl., vol. 2, 1871, p. 141.

Caracas Bay: from sponge, 10. v. 20, $10^{7}$.

Pilumnus andrewsii Rathbun.

Bull. Lab. Nat. Hist. State Univ. Iowa, vol. 4, 1898, p. 266, pl. 5, fig. 2.

Caracas Bay: in coral, 5. V.20, $1 \sigma^{7}$; from sponge, 10. V. 20, 1 ㅇ juv.

Length of carapace of $\sigma^{7} 5 \mathrm{~mm}$., width $7 \mathrm{~mm}$. In both specimens the sharp granulation on the upper portion of the manus is more extensive than in the female of larger size previously described; on the major manus of the male the granulation occurs in a narrow line at the proximal end of the outer surface, this line widening above; on the minor manus of the male and both of the female, the granulation is more widespread but still leaves the greater part of the surface smooth.

Pilumnus caribaeus Desbonne and Schramm.

Crust. Guadeloupe, 1867, p. 32.

Caracas Bay: 19. IV. 20, 2 ㅇ, each with a Rhizocephalid parasite under the abdomen.

Spanish Water: from mangrove roots, 8. IV.20, 1 ovigerous + ; from Siderastrea, 29.IV.20, 1 ovigerous $q=$ 3. IV. $20,10^{x} ; 18$. V. $20,10^{7}$.

Heteractaea ceratopus (Stimpson).

Pilumnus ceratopus Stimpson, Ann. Lyc. Nat. Hist. N. Y., vol. 7, 1860, p. 215 [87].

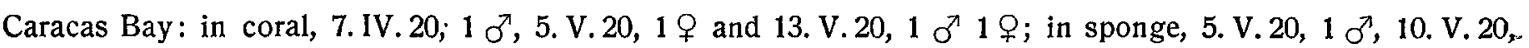
$3 \sigma^{7} 1$ \& 2 juv. and 11. V. 20, 1 \%; 19. V. 20, $1 \sigma^{7}$.

Eriphia gonagra (Fabricius).

Cancer gonagra Fabricius, Species Insectorum, 1781, p. 505.

Caracas Bay: 1. V.20, 1 ㅇ.

Domecia hispida Eydoux and Souleyet.

Voy. Bonite, vol. 1, Crust. 1842, p. 235.

Caracas Bay: 28.IV. 10, 1 \%; in coral, 7.IV. 20, $2 \sigma^{7} 1 \%$; in coral, 7.IV.20, $5 \sigma^{7} 4$ ㅇ (1 ovigerous) 9 juv

$\left(1 . \sigma^{7}\right.$ has an isopod parasite in the branchial cavity); 5. V. 20, 1 ㅇ.

Spanish water: in Porites furcata, 5. V.20, $10^{7}$. 
Family PINNOTHERIDE.

Pinnixa vanderhorsti Rathbun. (Plate III, figs. 7, 8, text-figs. 1 and 2).

Proc. Biol. Soc. Washington, vol. 35, 1922, p. 104.

Spanish Port: in sand, 6. V.20, $1 \sigma^{\nearrow}$ holotype; 7.IV.20, 1 small $\sigma^{\nearrow}$ paratype.

Length of carapace of holotype $3.4 \mathrm{~mm}$, width $6 \mathrm{~mm}$.

Carapace about twice as wide as long, narrowing toward the sides, smooth, punctate, without posterior ridge. Lateral marginal line disappearing toward the hepatic region. Front curved downward,

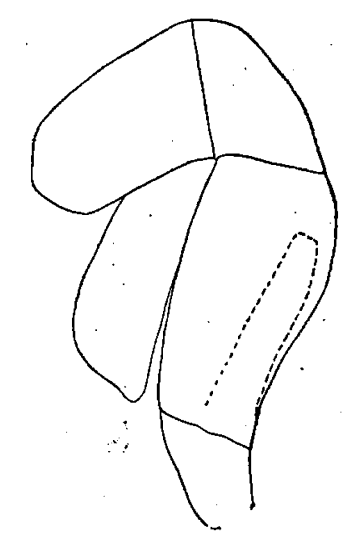

Fig. 1. fringed with hair, edge truncate. Orbits in dorsal view inclined forward and outward. Corneae black. Antennae longer than width of front.

Chelipeds small, upper half of outer surface hairy. A longitudinal ridge through the middle of the manus. Fingers subequal, horizontal, narrowly gaping, feebly denticulate, tips pointed, curved toward each other and overlapping. Ambulatory legs broad, third pair much the largest, fourth pair when extended reaching end of merus of preceding pair. Dactylus of third leg stout at base, moderately curved, dactyli of other legs more slender and straight. Merus of third leg a little over one and a half times as long as wide; propodus as broad as long.

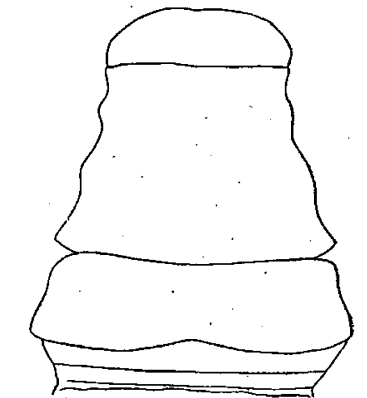

Fig. 2. Pinnixa vanderhorsti, left Abdomen of male with a narrow fringe of hair Pinnixa vanderhorsti, outer maxilliped of type $\sigma^{\top}$. along the proximal end of the third segment and bdomen of type $\sigma^{T}, \times 11.5$ continued on the sternum. Fourth, fifth and sixth segments fused, the resulting segment having undulating lateral margins. Terminal segment broadest at proximal end where it is only slightly broader than the contiguous portion of the preceding segment; free edge arcuate.

In the smaller male, paratype, the anterior angles of the front are not bent down and pinched in as in the holotype, and the front therefore appears wider at its distal end.

Near $P$. floridana ${ }^{1}$ ) Rathbun which has carapace, chelipeds and legs similar, but the orbits are transverse in dorsal view, the chelae rougher, the male abdomen with an oblong instead of a semioval terminal segment.

Pinnixa arenicola Rathbun. (Plate III, figs. 9, 10, text-figs. 3 and 4).

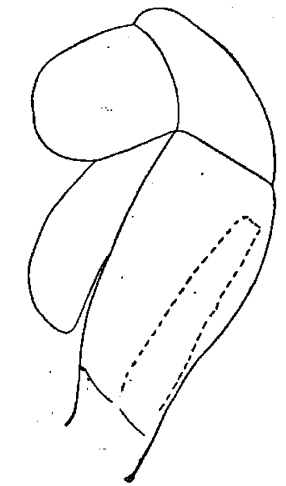

Fig. 3.

Pinnixa arenicola left outer maxilliped of type $\sigma^{\top}$.

Proc. Biol. Soc. Washington, vol. 35, 1922, p. 104.

Spanish Port: in sand, 16. IV.20, $1 \sigma^{7}$ holotype, distorted by a parasite in the left branchial chamber; 7.IV.20, 1 ovigerous female. Caracas Bay: 19.IV. 20, 1 ovigerous o.

Length of carapace of $\sigma^{7}$ holotype $3 \mathrm{~mm}$., width $6 \mathrm{~mm}$. Length of $Q$ (Spanish Port) $3.2 \mathrm{~mm}$., width $7.3 \mathrm{~mm}$.

The male bears a strong resemblance to that of the preceding. species, but differs as follows: The posterior margin of the carapace is longer and the antero-lateral region higher, making the shape appear more oblong. The front is narrower, its sides more convergent. The orbits are oblique, but the cornea is smaller than in $P$. vanderhorsti. The propodus of the cheliped has a more definite submarginal ridge running along manus and immovable finger. The propodus of the third ambulatory leg is narrower at its

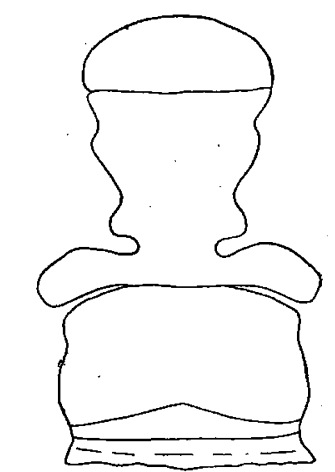

Fig. 4.

Pinnixa arenicola, abdomen of type $\sigma^{7}$, $\times 11.5$. proximal end, while the dactylus is slenderer and more curved.

The most striking feature of this species is the form of the male abdomen; the third segment

1) Bull. U.S. Nat. Mus., $\mathrm{N}^{0} 97,1918$, p. 138 , pl. 30 , figs. $4-7$, text-fig. 82 . 
is transversely oblong; the proximal and distal margins are slightly bilobed by a median emargination and the sides are faintly sinuous. As in the allied species, the fourth, fifth and sixth segments are fused; the fourth is very broad, having two transverse crescentic wings united medially by a narrow neck, which overlies the sternal somite bearing the second pair of ambulatories; the fifth and sixth segments are together urnshaped, intermittently widening; terminal segment still broader, its free edge arcuate. The appendages of the first segment are contiguous at the middle, beneath the narrowest part of the abdomen, and diverge before and behind that point.

The two females are larger than the male and the front widens a little distally after the constriction.

Parapinnixa hendersoni Rathbun.

Bull. U. S. Nat. Mus. No 97,1918 , p. 109, pl. 26, figs. 1-5, text-fig. 59.

Spanish Water: 26. IV.20, 1 large .

Caracas Bay: 10. V. 20, $10^{7} 2$, all small.

The $q$ from Spanish Water is a larger specimen than any before noted. The carapace is $4.5 \mathrm{~mm}$. long and $9.3 \mathrm{~mm}$. wide.

Family GRAPSIDE.

Grapsus grapsus (Linnaeus).

Cancer grapsus Linnaeus, Syst. Nat., ed. 10, vol. 1, 1758, p. 630.

Caracas Bay: 3. V. 20, 1 immature 9 ; 13. V. 20, 1 万.

Geograpsus lividus (Milne Edwards).

Grapsus lividus Milne Edwards, Hist. Nat. Crust., vol. 2, 1837, p. 85.

Caracas Bay: 7. IV.20, 11 young; under stones near shore, 18.V.20, $1 \sigma^{7}$ and 3. V. 20, 1 immature male.

Goniopsis cruentata (Latreille).

Grapsus cruentatus Latreille, Hist. Nat. Crust., vol. 6, 1803, p. 70.

Spanish Water: 20. V. 20, 1 ㅇ.

Pachygrapsus transversus (Gibbes).

Grapsus transversus Gibbes, Proc. Amer. Assoc. Adv. Sci., vol. 3, 1850, p. 181.

Spanish Water: 3. IV. 20, $10^{7}$.

Caracas Bay: under stones near shore, 2 juv.

Aratus pisonii (Milne Edwards).

Sesarma pisonii Milne Edwards, Hist. Nat. Crust., vol. 2, 1837, p. 76, pl. 19, figs. 4 and 5.

Spanish Water: 3.IV.20, 1 ovigerous $ᄋ$; from mangrove roots, 8. IV. 20, $1 \delta^{7} 1$ ovigerous $ᄋ$.

Plagusia depressa (Fabricius).

Cancer depressus Fabricius, Syst. Entom., 1775, p. 406.

Caracas Bay: 7.IV. 20, 1 juv.; 1. V. $20,1 \sigma^{\lambda}$ juv. 1 \%; 3. V. $20,1 \sigma^{7}$; 25. V. 20,1 juv.; under stones near shore, 3. V. $20,10^{7}$ juv.

Spanish Bay: among stones in the surf, 11. V.20, 2 juv.

Percnon gibbesi (Milne Edwards).

Acanthopus gibbesi Milne Edwards, Ann. Sci. Nat., ser. 3, Zool., vol. 20, 1853, p. 180 [146].

Caracas Bay: from coral, 29.IV.20, 1 \%; from stones, 30. IV. 20, 1 \%; under stones near shore, 3.V.20, $3 \sigma^{\top}$, 1 ovigerous,+ 1 juv.

Family GeCarcinide.

Cardisoma guanhumi Latreille.

Encyc. Méth., Hist. Nat., Entom., vol. 10, 1825, p. 685.

Caracas Bay; 7. IV. 20, $4 \delta^{7} 2$ Q.

Digs deep holes and is captured in the evening and eaten. 
Gecarcinus ruricola (Linnaeus).

Cancer ruricola Linnaeus, Syst. Nat., ed. 10, vol. 1, 1758, p. 626.

Plantation Hato: 28. IV. 20, $1 \sigma^{t}$ of medium size.

Plantation Brakke Put: 15. V. 20, 1 large $\sigma^{x}$.

Gecarcinus lateralis (Freminville).

Ocypoda lateralis Freminville, Ann. Sci. Nat., ser. 2, Zool., vol. 3, 1835, p. 224.

Caracas Bay: 7.IV. 20, 1 small $\sigma^{7}$; 26. V.20, 1 small $\sigma^{7}$.

Family OcYPODIDE.

Uca pugnax rapax (Smith).

Gelasimus rapax Smith, Trans. Connecticut Acad. Arts and Sci., vol. 2, 1870, p. 134, pl.2, fig. 2, pl. 4, fig. 3.

Caracas Bay: in small pools among mangroves, 26.1V.20, $15 \sigma^{7} 5$ q .

Uca speciosa (Ives).

Gelasimus speciosus Ives, Proc. Acad. Nat. Sci. Philadelphia, 1891, p. 179, pl. 5, figs. 5 and 6.

Caracas Bay: 14. IV. 20, $2 \sigma^{7} 1$ \%

Uca leptodactyla Rathbun.

In Rankin, Ann. New York Acad. Sci., vol. 11, 1898, No 12, p. 227.

Spanish Water: 26.IV. 20, 1 \%.

Family MAJIDE = INACHID $Æ$.

Stenorynchus sagittarius (Fabricius).

Cancer sagittarius Fabricius, Ent. Syst. emend. et auct., vol. 2, 1793, p. 442 (part).

Spanish Water: 17. V. 20, 1 large $\delta^{t}$.

\section{Podochela macrodera Stimpson.}

Ann. Lyc. Nat. Hist. N. Y., vol. 7, 1860, p. 196.

Caracas Bay: in coral, 7. IV.20, 1 o.

\section{Acanthonyx petiverii Milne Edwards.}

Hist. Nat. Crust., vol. 1, 1834, p. 343.

Caracas Bay: 8. IV. 20, $10 \sigma^{7} 9 \%$ (1 ovigerous).

West Punt: 14. V. 20, $40^{\text {ग } 2} 2$ 우 (1 ovigerous).

Herbstia depressa Stimpson.

Ann. Lyc. Nat. Hist. N. Y., vol. 7, 1860, p. 185 [57].

Caracas Bay: from sponge, 10. V.20, $10^{\pi} 2 \%$ (1 ovigerous).

Hemus cristulipes A. Milne Edwards.

Crust. Rég. Mex., 1875, p. 88, pl. 16, figs. 1-1 $f$.

Spanish Water: in Porites furcata, 5. V.20, 3 q. One has a Rhizocephalid parasite under the abdomenn.

Thoe puella Stimpson.

Ann. Lyc. Nat. Hist. N. Y., vol. 7, 1860, p. 178.

Caracas Bay: 1. V. 20, $10^{7} 1$ ovigerous $q$; in coral, 2. IV.20, 2 immature $q$.

Pitho aculeata (Gibbes).

Hyas aculeata Gibbes, Proc. Amer. Assoc. Adv. Sci., vol. 3, 1850, p. 171.

Caracas Bay: in sand, 13. V. 20, $10^{7}$. 
Mithrax acuticornis Stimpson, var.

Bull. Mus. Comp. Zoöl., vol. 2, 1871, p. 116,

Caracas Bay : from sponge, 10. V. 20, $2 \sigma^{7} 1$ ㅇ 7 juv; in coral, 13. V. 20,1 juv.; 5.V. $20,1 \sigma^{7}$.

The single male has a carapace length on the median line of $26.5 \mathrm{~mm}$., length including horns $28.7 \mathrm{~mm}$., width excluding spines $25 \mathrm{~mm}$., including spines $27.4 \mathrm{~mm}$.

None of the Curaçao specimens show a trace of spines on the manus; they have a more oblong, less pyriform carapace, shorter rostral horns and shorter, stouter legs than typical specimens from the west coast of Florida. .

\section{Mithrax verrucosus Milne Edwards.}

Mag. de Zool,, vol. 2, 1832, pl. 4.

Caracas Bay: in coral, 7.IV. 20, $1 \sigma^{7}$ juv.; under stones, 18.V.20, 1 \%; in coral, 7.IV.20, $1 \sigma^{7}$ representing a very young stage, identification uncertain.

Spanish Bay: among stones in the surf, 11. V. 20, 1 \% juv.

Spanish Water: in Porites furcata, 5. V. 20, $1 \sigma^{\pi}$ juv.

\section{Mithrax hispidus (Herbst).}

Cancer hispidus Herbst, Naturg. d. Krabben u. Krebse, vol. 1, 1790, p. 247, pl. 18, fig. 100.

Caracas Bay: in sponge, 3. V. 20, 1 immature $\sigma^{\top}$.

Mithrax caribbaeus Rathbun.

Proc. Biol. Soc. Washington, vol. 33, 1920, p. 23.

Caracas Bay: 19.IV. 20, $10^{\nearrow}$ juv.

Spanish Water: from Porites furcata, 13. IV. 20, 1 juv.

Mithrax pleuracanthus Stimpson.

Bull. Mus. Comp. Zoöl., vol. 2, 1871, p. 116.

Caracas Bay: in sponge, 10.V.20, 1 juv.

\section{Mithrax tortuga Rathbun.}

Proc. Biol. Soc. Washington, vol. 33, 1920, p. 23.

Caracas Bay: in coral, 2. IV.20, 1 juv.

Extreme length of carapace $6.5 \mathrm{~mm}$., extreme width $6.5 \mathrm{~mm}$. This small specimen shows the characters of the half-grown type female, except that its carapace is narrower.

Mithrax sculptus (Lamarck).

Maia sculpta Lamarck, Hist. Nat. Anim. sans Vert., vol. 5, 1818, p. 242.

Caracas Bay: 19. IV.20, $2 \sigma^{7} 1$ \%; in coral, 13. V. 20, $1 \sigma^{7}$.

Spanish Port: 10. IV.20, $10^{7}$.

\section{Mithrax coryphe (Herbst).}

Cancer coryphe Herbst, Naturg. d. Krabben u. Krebse, vol. 3, Heft 2, 1801, p. 8.

Caracas Bay: 8.IV. 20, 1 juv.; 1. V. 20, $1 \sigma^{\gamma} 1$ ㅇ juv.; under stones near shore, 3. V.20, $1 \sigma^{\pi}$; from coral,

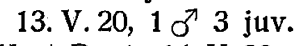

West Punt: 14. V. 20, 3 juv.

Mithrax forceps (A. Milne Edwards).

Mithraculus forceps A. Milne Edwards, Crust. Rég. Mex., 1875, p. 109, pl. 23, figs. 1-1c.

Spanish Water: 3.IV. 20, $4 \delta^{7} 4$ 오 (2 ovigerous, 2 juv.); 17. IV. $20.3 \delta^{7} 3$ ovigerous 9 ; from mangrove roots, 8. IV. 20, $1 \sigma^{7}$; on Siderastrea, 29. IV.20, 3 ovigerous ; from Porites furcata, 5. V. 20,4 juv.

Caracas Bay: 19. V. 20, $1 \sigma^{\top}$; from coral, 23. IV. 20, 1 juv., 28. IV. $201 \sigma^{7}$ and 5. V. $201 \sigma^{\top}$; from sponge,

10. V. $20,9 \sigma^{7} 4$ 우 (1 ovigerous). 
Mithrax ruber (Stimpson).

Mithraculus ruber Stimpson, Bull. Mus. Comp. Zoöl., vol. 2, 1871, p. 118.

West Punt: 14. V. 20, $10^{7}$.

Caracas Bay: 7. IV. 20,1 ovigerous $\rho$; from a stone at the shore, 30. IV.20, $1 \sigma^{7} 1$ \% in coral, 7. IV. 20, $1 \sigma^{7} 3$ juv.; 13. V.20, 1 immature + ; and 23.IV.20, 1 क with Rhizocephalid parasite under abdomen; in sponge, 3 . V. 20,1 ovigerous + .

Mithrax cinctimanus (Stimpson).

Mithraculus cinctimanus Stimpson, Amer. Journ. Sci., vol. 29, 1860, p. 132.

Caracas Bay: 1. V. 20, 1 q; from coral, 7.IV. 20, 1 q.

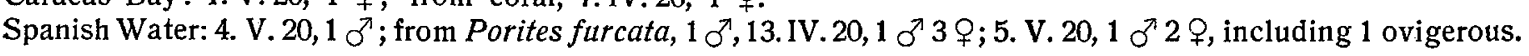

Teleophrys cristulipes Stimpson.

Ann. Lyc. Nat. Hist. N. Y., vol. 7, 1860, p. 190 [62].

Caracas Bay: from a stone on shore, 30. IV. 20, 1 ovigerous $O$; in sponge, 3. V.20, $2 \sigma^{7}$.

Macrocoeloma trispinosum (Latreille).

Pisa trispinosa Latreille, Encyc. Méth., Hist. Nat., vol. 10, 1825, p. 142.

Spanish Water: 12. IV. 20, 2 juv.; from mangrove roots, 8. IV.20, 1 juv.; from Porites furcata, 5.V. 20, 1 万'?

Macrocoeloma trispinosum (Latreille), var.

Pericera trispinosa von Martens, Arch. f. Naturg., vol. 38, pt. 1, 1872, p. 84, pl. 4 , figs. $4 a$ and $4 c$. Spanish Water: 3.IV.20, 1 or.

Macrocoeloma diplacanthum (Stimpson).

Pericera diplacantha Stimpson, Ann. Lyc. Nat. Hist. New York, vol. 7, 1860, p. 183.

Caracas Bay: 19. IV. 20, $1 \sigma^{\gamma}$, encrusted with algae.

Microphrys bicornutus (Latreille).

Pisa bicornuta Latreille, Encyc. Méth., Hist., Nat., Insectes, vol. 10, 1825, p. 141.

Spanish Port: 10.IV. 20, $40^{\pi} 6$ ㅇ (1 ovigerous).

Spanish Water: 3.IV. 20, 1 \% ; from Porites furcata, 5. V. 20, $10^{7}$

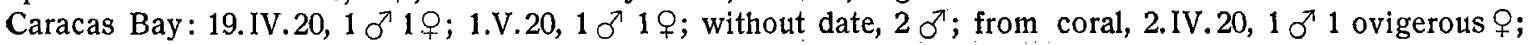

7. IV. $20,2 \sigma^{7} 1$ ovigerous $P$ and 13. V. 20,5 juv.; from sponge, 10. V. 20,1 juv.

\section{Larval forms.}

Two sorts of megalops were obtained, impossible of identification on account of our fragmentary knowledge of life histories. One from West Punt, 14. V. 20, is of large size, carapace $5 \mathrm{~mm}$. long, $4 \mathrm{~mm}$. wide, front deeply cut into three long spines; it is probably one of the Grapsoidea. Two specimens of a much smaller form, carapace $2.7 \mathrm{~mm}$. long by $1.8 \mathrm{~mm}$. wide, were taken from coral in Caracas Bay, 7.IV.20; the front has subrectangular outer angles, rounded off, and a small, subtriangular, median lobe. 


\section{LIST OF ILLUSTRATIONS.}

Randallia curaçaoensis, ovigerous $\$$, holotype, carapace $8.4 \mathrm{~mm}$. long.

Fig. 1. Dorsal view.

Fig. 2. Ventral view.

Fig. 3. Left side in profile.

Xanthias vestitus, $\sigma^{\nearrow}$ holotype, carapace $4.6 \mathrm{~mm}$. long.

Fig. 4. Dorsal view.

Fig. 5. Ventral view.

Same species, $\sigma$, paratype, propodus $5 \mathrm{~mm}$. long.

Fig. 6. Right chela and wrist, outer view.

Pinnixa vanderhorsti, $\sigma^{7}$, holotype, carapace $3.4 \mathrm{~mm}$. long.

Fig. 7. Dorsal view.

Fig. 8. Ventral view.

Pinnixa arenicola, $\sigma^{\lambda}$, holotype, carapace $3 \mathrm{~mm}$. long.

Fig. 9. Dorsal view.

Fig. 10. Ventral view. 


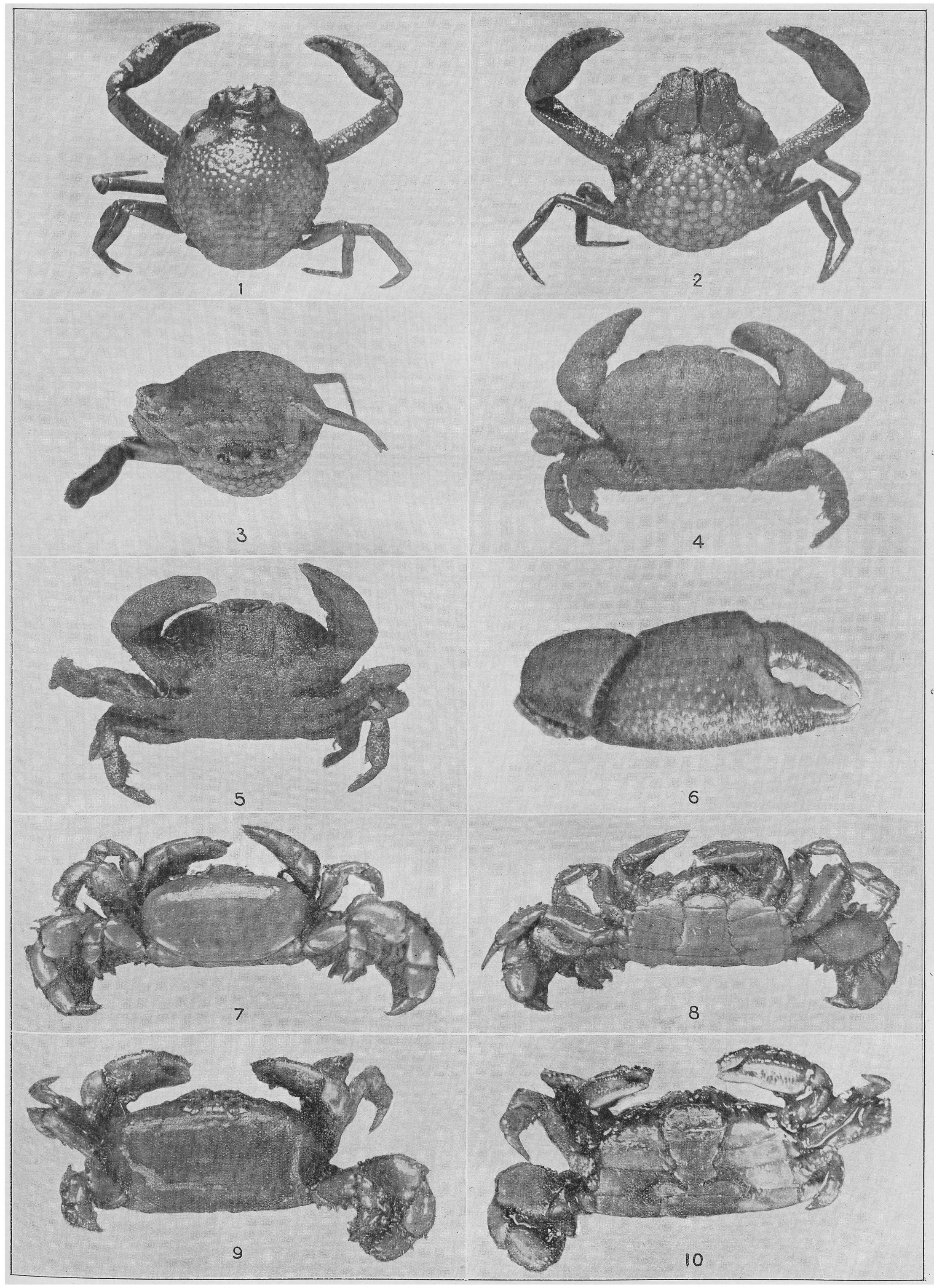

